\title{
ANALISIS KEMAMPUAN PENALARAN MATEMATIK SISWA SMP PADA SOAL-SOAL MATERI SEGI EMPAT DAN SEGITIGA
}

\author{
Puji Astuti ${ }^{1}$, Ratna Sariningsih ${ }^{2}$ \\ 1,2 IKIP Siliwangi, Jalan. Terusan. Jenderal. Soedirman, Cimahi \\ 1pastuti483@yahoo.com, ${ }^{2}$ ratnasari_ning@ymail.com
}

\begin{abstract}
This research aims to determine the ability of mathematical reasoning of students of class VIII SMP about the rectangular and triangular material. The research method used is descriptive qualitative research. Subjects in this study were 30 students in one junior high school in Cianjur District. The reasoning ability reasoning instrument used is an essay form. Indicator used in this research there are 7 indicators of reasoning ability that is drawing logical conclusion; provide explanations using images; establishing direct proof, indirect proof, and by proving by mathematical induction; filed the infringement rules, checked the validity of the arguments and compiled a valid argument; propose opponent example; estimate answers and solution processes; using relationship patterns to analyze, make analogies, generalizations, and compile and test conjectures.
\end{abstract}

Keywords: Mathematical Reasoning, Junior High School Students

\begin{abstract}
Abstrak
Penelitian ini bertujuan untuk mengetahui kemampuan penalaran matematik siswa kelas VIII SMP mengenai materi segiempat dan segitiga. Metode penelitian yang digunakan adalah penelitian deskriptif kualitatif. Subjek dalam penelitian ini adalah 30 siswa di salah satu SMP di Kabupaten Cianjur. Instrumen tes kemampuan penalaran yang digunakan adalah bentuk essay. Indikator yang digunakan dalam penelitian ini ada 7 indikator kemampuan penalaran yaitu menarik kesimpulan logis; memberi penjelasan menggunakan gambar; menyusun pembuktian langsung, pembuktian tak langsung, dan dengan pembuktian dengan induksi matematika; mengajukan aturan infrensi, memeriksa validitas argument dan menyusun argument yang valid; mengajukan lawan contoh; memperkirakan jawaban dan proses solusi; menggunakan pola hubungan untuk menganalisis, membuat analogi, generalisasi, dan menyusun serta menguji konjektur.
\end{abstract}

Kata Kunci: Penalaran Matematik, Siswa SMP

How to cite: Astuti, P., Sariningsih, R. (2018). Analisis Kemampuan Penalaran Matematik Siswa Smp Pada Soal-Soal Materi Segi Empat Dan Segitiga. JPMI - Jurnal Pembelajaran Matematika Inovatif, 1 (4), 807-818.

\section{PENDAHULUAN}

Matematika adalah mata pelajaran yang wajib ditempuh pada setiap jenjang pendidikan. Namun sampai saat ini matematika dianggap sebagai mata pelajaran yang sukar dipahami oleh sebagian siswa dibanding dengan mata pelajaran lain. Padahal matematika mempunyai peranan penting dalam berbagai bidang di kehidupan sehari-hari (Hidayat, \& Sariningsih, 2018).

Matematika sebagai dasar logika dalam penalaran dan penyelesaian kuantitatif yang dipergunakan dalam ilmu lain, satu tujuannya matematika di sekolah adalah menggunakan 
penalaran dalam pola dan sifat, kemudian melakukan manipulasi dalam matematika yang membuat generalisasi, menyusun bukti, atau menjelaskan gagasan dan pernyataan matematika (Riyanto, 2011). Ini pun didukung oleh Widjaya (2010) menyatakan bahwa "mathematical reasoning is the founfation for the construction of mathematical knowledge." Hal ini juga menjadikan penalaran matematika itu fondasi untuk mendaptalan dan menkonstruk pengetahuan matematika. Namun, justru salah satu hal yang menyebabkan beberapa siswa gagal dalam menguasai pokok-pokok bahasa dalam menyelesaikan persoalan matematika yang diberikan. Penalaran siswa dalam matematika terlihat pada kemampuan siswa menganalisis masalah matematika yang ada untuk mendapatkan jawaban yang logis.

Selain model pembelajaran, hasil proses belajar matematika siswa juga ditentukan oleh faktor intern dari dalam siswa (Slameto, 2010). Salah satu faktor intern tersebut ialah penalaran. Sobur (2003) mendefinisikan bahwa "penalaran sebagai kegiatan berfikir seturut atas kelurusan berpikir atau sesuai dengan hokum logika. Penalaran yang sebagai kegiatan berfikir logis ini belum menjamin bahwa kesimpulan itu ditarik atau pengetahuan yang hasilnya pasti benar."

Anggapan siswa bahwa matematika itu membingungkan merupakan cerminan dari masih lemahnya kemampuan penalaran matematis siswa, sebaliknya bagi siswa yang memanfaatkan kemampuan penalaran matematis dalam belajarnya akan lebih merasakan keberartian matematika. Oleh karena itu, penggunaan kemampuan penalaran matematis di dalam pembelajaran matematika utamanya perlu mendapatkan perhatian lebih.

Siswa yang memiliki tingkat penalaran matematis tinggi terlihat lebih mudah dalam memahami dan mengerjakan soal tes penalaran matematis, sedangkan siswa dengaan tingkat penalaran matematis sedang sedikit mengalami kesulitan dalam memahami dan mengerjakan soal tes penalaran matematis dan siswa yang memiliki tingkat penalaran matematis rendah mengalami kesulitan dalam memahami soal tes penalaraan matematis (Hermawan \& Hidayat, 2018; Hidayat, 2017; Hidayat \& Prabawanto; 2018; Isnaeni, Fajriyah, Risky, Purwasih, \& Hidayat, 2018; Sholihat, Hidayat, \& Rohaeti, 2018; Yusdiana \& Hidayat, 2018). Keadaan tersebut sejalan dengan penelitian yang dilakukan Adegoke (2013) menyatakan bahwa "tingkat kemampuan penalaran matematika memainkan peran utama dalam pencapaian matematika."

Selain itu, Riyanto \& Siroj (2011) dalam penelitiannya menyimpulkan bahwa "terdapat perbedaan yang signifikan antara siswa yang memiliki tingkat penalaran tinggi, sedang, dan rendah. Sehingga skor prestasi matematika siswa yang memiliki kemampuan penalaran tinggi lebih baik daripada siswa yang memiliki tingkat penalaran sedang dan siswa yang memiliki tingkat penalaran sedang lebih baik daripada siswa yang memiliki tingkat penalaran rendah."

\section{METODE}

Penelitian yang digunakan dalam penelitian ini adalah studi kasus, jenis penelitian kualitatif yang menggunakan metodologi penelitian deskriptif. Subjek dalam pelaksanaan penelitian ini adalah siswa kelas VIII SMP Plus Al-ittihad yang berjumlah 30 orang.

Menurut Arikunto (2009) menyatakan bahwa "Objek segala sesuatu yng menjadi titik pusat dalam pengamatan karena penilai yang menginginkan informasi tersebut." Objek dalam penelitian ini adalah kemampuan penalaran matematik siswa pada pembelajaran segiempat dan segitiga. Teknik pengumpulan data yang digunakan pada penelitian ini adalah teknik pengukuran dan teknik komunikasi langsung. 
Tes yang digunakannya pada pelaksanaan penelitian ini adalah tes tertulis. Menurut Nawawi (2005) tes essay adalah "tes yang mengkehendaki testee (peserta tes) yang memberikan jawaban dalam bentuk esay atau kalimat-kalimat yang disusun sendiri." Prosedur dalam penelitian ini terdiri dari 3 tahap, yaitu : 1) tahap persiapan, 2) tahap pelaksanaan, 3) tahap akhir.

Tahap persiapan : (1) Melakukan pra riset siswa SMP PLUS AL-ITTIHAD CIANJUR; (2) Menyiapkan instrument penelitian untuk tes soal kemampuan penalaran matematik; (3) Merevisi instrument penelitian berdasarkan hasil validasi.

Tahap Pelaksanaan: (1) Memberikan tes kepada siswa kelas VIII SMP PLUS AL-ITTIHAD CIANJUR; (2) Menganalisis jawaban subjek penelitian.

Tahap akhir : (1) Menganalisis data yang diperoleh hasil tes; (2) Mendeskripsikan hasil analisis data dan memberikan kesimpulan sebagai jawaban dari rumusan masalah; (3) Menyusun laporan penelitian.

Dalam penelitian ini data dikumpulkan melalui tes tertulis yang bertujuan untuk mengetahui kemampuan penalaran matematis siswa. Tes berbentuk uraian atau essay yang dilaksanakan di akhir penelitian. Soal disesuaikan dengan indikator-indikator kemampuan penalaran matematis. Sebelum digunakan, soal-soal tes divalidasi oleh pakar. Wawancara dalam penelitian ini digunakan untuk mengetahui gambaran kemampuan penalaran matematis siswa dan sebagai data pendukung hasil tes siswa. Wawancara dilakukan setelah tes diberikan. Jenis wawancara yang digunakan adalah wawancara tidak terstruktur, yang mana peneliti ini tidak menggunakan pedoman wawancaranya diantaranya telah tersusun secara sistematis juga lengkap dalam pengumpulan data tersebut.

Pada analisis data tes, adapun pedoman penskoran yang digunakan adalah sebagai berikut :

Tabel 1. Rubrik Penilaian Penalaran Matematik

\begin{tabular}{lc}
\multicolumn{1}{c}{ Rubrik Penilaian } & Skor \\
\hline $\begin{array}{l}\text { Dapat menjawab semua aspek pertanyaan tentang penalaran dan dapat } \\
\text { dijawab dengan benar dan jelas atau lengkap }\end{array}$ & 4 \\
$\begin{array}{l}\text { Dapat menjawab hampir semua aspek pertanyaan tentang penalaran } \\
\begin{array}{l}\text { Dapat menjawab hanya sebagian aspek pertanyaan tentang penalaran dan } \\
\text { dijawab dengan benar }\end{array}\end{array}$ & 2 \\
$\begin{array}{l}\text { Menjawab tidak sesuai atas aspek pertanyaan tentang penalaran atau } \\
\text { menarik kesimpulan salah }\end{array}$ & 1 \\
Tidak ada jawaban & 0 \\
\hline
\end{tabular}

(Hutajulu, 2010) 
Dalam menentukan kategori tingkat kemampuan penalaran siswa dalam menyelesaikan soalsoal. Nilai kemampuan penalaran matematis dalam siswa dikonversikan dalam bentuk kualitatif dengan melihat pada pedoman-pedoman penilaian seperti ditunjukkan tabel berikut:

Tabel 2. Nilai Kualitatif Kemampuan Penalaran Siswa

\begin{tabular}{cc}
\hline Nilai & Kategori \\
\hline $81-100$ & Sangat baik \\
$61-80$ & Baik \\
$41-60$ & Cukup \\
$21-40$ & Kurang \\
$0-20$ & Sangat Kurang \\
\hline
\end{tabular}

(Modifikasi Arikunto, 2011)

Adapun tahap awal dalam analisis data wawancara yaitu proses pemilihan, pemusatan perhatian data-data yang muncul dalam catatan lapangan (reduksi data). Dalam penelitian kualitatif, data masih berupa data-data yang mentah yang jumlahnya sangat banyak yang bersifat sangat deskriptif sehingga tidak dapat langsung dianalisis. Data wawancara dikonversikan dalam bentuk tulisan atau transkip percakapan. Kemudian peneliti memilih beberapa bagian percakapan yang dapat diproses pada langkah selanjutnya.

\section{HASIL DAN PEMBAHASAN}

\section{Hasil}

Penelitian ini dilaksanakan pada salah satu kelas VIII SMP Plus Al Ittihad Cianjur. Sesuai dengan pertanyaan penelitian yang telah dikemukakan sebelumnya, maka untuk menjawab pertanyaan penelitian tersebut dilakukan pembahasan dan analisis jawaban untuk mengungkap kemampuan penalaran matematik yang dilakukan siswa dari setiap jawaban soal tes yang dijadikan sampel penelitian. Mendeskripsikan kemampuan penalaran siswa dalam menyelesaikan soal segiempat dan segitiga pada tiap soal. Sampel penelitian berjumlah 30 siswa. Data dari hasil penelitian ini yaitu berupa hasil belajar siswa yang pengumpulan datanya menggunakan instrumen berupa soal tes uraian sebanyak 7 soal.

Data tes diperoleh dari analisis jawaban siswa berdasarkan acuan pedoman penskoran kemampuan penalaran matematis. Adapun skor kemampuan penalaran matematis siswa dapat dilihat pada Tabel 3 berikut.

Tabel 3. Kategori Kemampuan Penalaran Matematis Siswa

\begin{tabular}{cccc}
\hline Nilai & Kategori & Frekuensi & Persentase \\
\hline $\mathbf{8 1 - 1 0 0}$ & Sangat baik & 5 & $16,67 \%$ \\
$\mathbf{6 1 - 8 0}$ & Baik & 8 & $26,67 \%$ \\
$\mathbf{4 1 - 6 0}$ & Cukup & 11 & $36,66 \%$ \\
$\mathbf{2 1 - 4 0}$ & Kurang & 6 & $20 \%$ \\
$\mathbf{0 - 2 0}$ & Sangat Kurang & 0 & $0 \%$ \\
\hline & Jumlah & 30 & $100 \%$ \\
\hline
\end{tabular}

Tabel 3 merupakan hasil penilaian tes kemampuan penalaran matematis siswa dengan jumlah rentang penilaian $0-100$ yang disajikan dalam bentuk distribusi frekuensi untuk 
memudahkan membaca data dan disertai dengan kategori penilaian yaitu sangat baik, baik, cukup, kurang, dan sangat kurang. 16,67 \% siswa termasuk kategori sangat baik, $26.67 \%$ termasuk kategori baik, 36,66 \% siswa termasuk kategori cukup, $20 \%$ siswa termasuk kategori kurang, dan $0 \%$ siswa termasuk kategori sangat kurang. Berikut adalah persentase ketercapaian tiap-tiap indikator kemampuan penalaran matematis terlihat pada Tabel 4.

Tabel 4. Persentase Ketercapaian Indikator Kemampuan Penalaran Matematis Siswa

\begin{tabular}{clc}
\hline No & \multicolumn{1}{c}{ Indikator } & Presentase \\
\hline 1 & Menarik kesimpulan logis & $45 \%$ \\
2 & Memberi penjelasan menggunakan gambar & $44,17 \%$ \\
3 & $\begin{array}{l}\text { Menyusun pembuktian langsung, pembuktian tak langsung, dan } \\
\text { dengan pembuktian dengan induksi matematika }\end{array}$ & $45 \%$ \\
& & \\
4 & Mengajukan aturan infrensi, memeriksa validitas argument dan & $41,67 \%$ \\
& $\begin{array}{l}\text { menyusun argument yang valid } \\
5\end{array}$ & Mengajukan lawan contoh \\
6 & Memperkirakan jawaban dan proses solusi & $33,33 \%$ \\
7 & $\begin{array}{l}\text { Menggunakan Pola Hubungan untuk menganalisis,membuat } \\
\text { analogi, generalisasi, dan menyusun serta menguji konjektur }\end{array}$ & $32,5 \%$ \\
& & \\
\hline
\end{tabular}

Berdasarkan Tabel 4 terlihat bahwa terdapat dua indikator yang persentase indikator kemampuan penalaran matematisnya paling tinggi yaitu Menarik kesimpulan logis dan Menyusun pembuktian langsung, pembuktian tak langsung, dan dengan pembuktian dengan induksi matematika sebesar $45 \%$. Sementara persentase kemunculan indikator kemampuan penalaran yang paling rendah yaitu indikator memperkirakan jawaban dan proses solusi yaitu sebesar $32,5 \%$.

\section{Pembahasan}

Untuk soal no 1 itu dilihat dari indikator yang pertama dari kemampuan penalaran matematik yaitu menarik kesimpulan logis, berikut soalnya :

"Pak Budi memiliki seorang anak laki-laki dan seorang anak perempuan. Ia mempunyai 2 bidang tanah, yang satu berbentuk persegi panjang dengan ukuran panjang $14 \mathrm{~m}$ dan lebar 4 $\mathrm{m}$. Satu bidang tanah lagi berbentuk belah ketupat dengan panjang diagonal satunya $14 \mathrm{~m}$ dan diagonal duanya $4 \mathrm{~m}$. Pak Budi ingin memberikan tanah terluas kepada anak laki-lakinya, maka simpulkanlah tanah mana yang paling luas. Jelaskan alasan yang mendasari kesimpulan tersebut?"

Berikut lembar jawaban siswa :

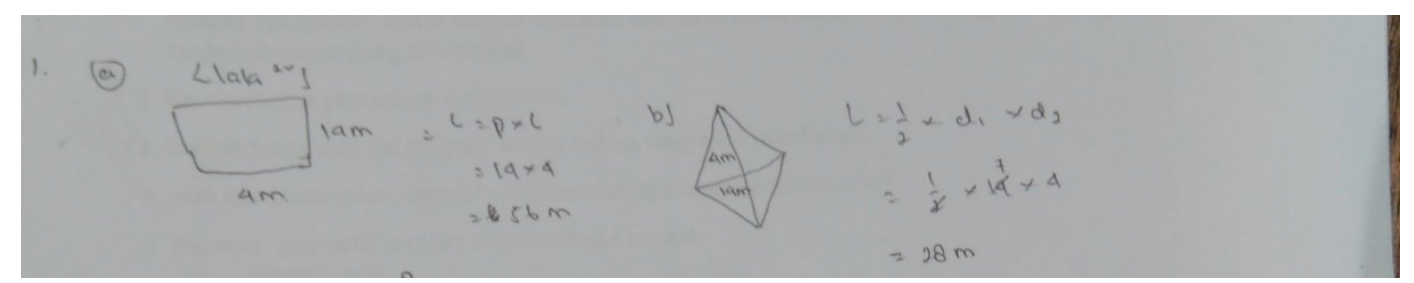

Gambar 1. Jawaban Tertulis Soal Nomor 1 


\section{Analisis kesalahan}

Siswa yang mengerjakan soal tersebut tidak memberikan kesimpulan bahwa tanah yang mana yang paling luas, siswa hanya mengerjakan langkah untuk mencari luas dari persegi panjang dan belah ketupat, dan dalam pengerjaannya pun siswa tersebut tidak memberikan keterangan bahwa jawaban tersebut merupakan cara mencari luas dari persegi panjang dan belah ketupat.

\section{Wawancara:}

P : "Nopy kenapa hasil akhirnya tidak dijelaskan?"

S : "Iya bu, Nopy kira hanya mencari kedua luasnya saja bu."

$\mathrm{P}$ : " Iya jawaban mencari kedua luasnya sudah benar, tapi nanti berikan penjelasan dan kesimpulannya ya luas mana yang paling luasnya, agar lebih jelas. “

S : "Iya bu"

Berdasarkan wawancara diatas, subjek tidak menyimpulkan hasilnya karena kurang faham terhadap soal yang diberikan sehingga menjawab kedua luasnya.

Untuk soal no 2 itu dilihat dari indikator yang kedua dari kemampuan penalaran matematik yaitu memberi penjelasan menggunakan gambar, berikut soalnya :

"Diketahui segitiga $\mathrm{ABC}$ dan segitiga $\mathrm{PQR}$ sebangun dengan sudut $\mathrm{A}=31^{\circ}$, sudut $\mathrm{B}=$ $112^{\circ}$, sudut $\mathrm{P}=37^{\circ}$, dan sudut $\mathrm{Q}=31^{\circ}$, Gambarkan sisi - sisi mana yang sebanding!"

Berikut jawaban siswa :

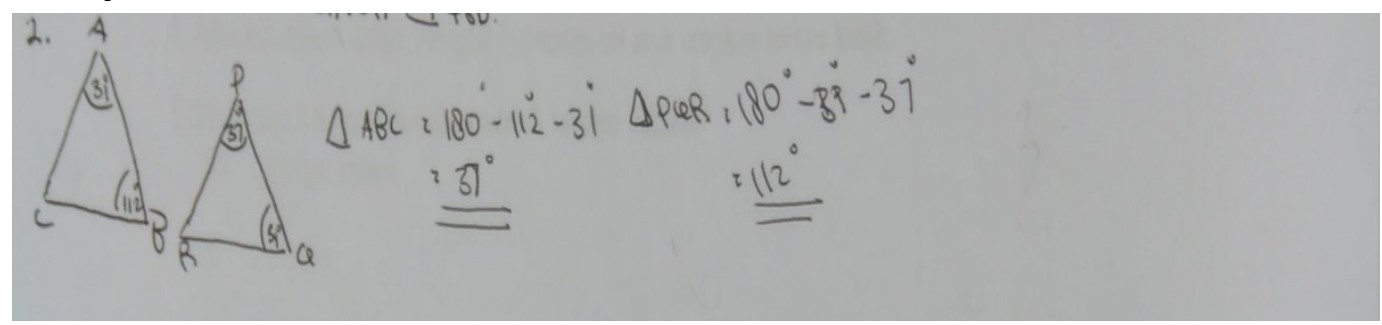

Gambar 2. Jawaban Tertulis Soal Nomor 2

\section{Analisis kesalahan}

Siswa yang mengerjakan soal tersebut tidak mengerti dengan apa yang ditanyakan dari unsur -unsur soal tersebut, sehingga jawaban tersebut tidak fokus terhadap jawaban yang sesuai.

\section{Wawancara}

P : " Hadiyan kenapa jawabannya tidak disimpulkan?"

S : "iya bu, nadya terburu-buru mengerjakannya."

P : "Seharusnya disimpulkan, jadi terlihat hasilnya ya "

S : "Iya bu lain kali Hadiyan jelaskan kesimpulannya."

Berdasarkan wawancara diatas, subjek tidak terlalu memperhatikan terhadap soalnya,sehingga jawaban tidak sesuai dengan soal yang diberikan.

Untuk soal no 3 itu dilihat dari indikator yang ketiga dari kemampuan penalaran matematik yaitu menyusun pembuktian langsung, pembuktian tak langsung, dan dengan pembuktian dengan induksi matematika, berikut soalnya : 
"Diberikan trapesium sama kaki $\mathrm{ABCD}$ mempunyai sisi $\mathrm{AB}$ sejajar dengan sisi $\mathrm{CD}$. Diagonal-diagonalnya berpotongan di E. Apakah segitiga ABE kongruen dengan segitiga CED?"

Berikut lembar jawaban siswa :

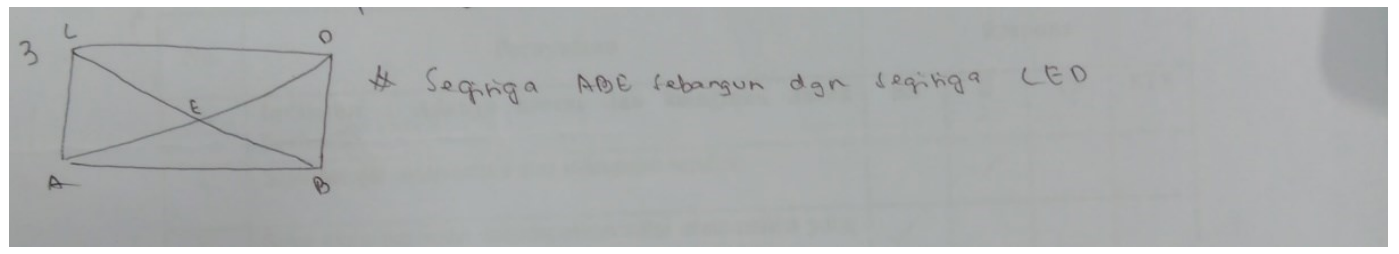

Gambar 3. Jawaban Tertulis Soal Nomor 3

\section{Analisis kesalahan}

Siswa yang mengerjakan soal tersebut belum memahami konsepnya dan belum mengerti dengan pertanyaannya, sehingga siswa tersebut hanya menggambarkannya saja, dan gambarnya pun tidak sesuai.

\section{Wawancara :}

P : " Salsa sudahkah mengerti dengan soalnya?"

$\mathrm{S}$ : " Belum bu, Salsa bingung"

$\mathrm{P}$ : “ Bingungnya yang mana Salsa?"

$\mathrm{S}$ : "Bingung dengan kongruennya bu"

P : "Belajar lagi ya Salsa"

S : "Iya bu terimakasih."

Berdasarkan wawancara diatas, subjek mengalami kesulitan dalam memahami konsep terhadap materi tersebut sehingga jawabannya tidak lengkap.

Untuk soal no 4 itu dilihat dari indikator yang keempat dari kemampuan penalaran matematik yaitu mengajukan aturan infrensi, memeriksa validitas argument dan menyusun argument yang valid, berikut soalnya :

"Selidiki apakah segitiga-segitiga dengan ukuran $24 \mathrm{~cm}, 32 \mathrm{~cm}$, dan $40 \mathrm{~cm}$ sebangun dengan segiriga yang sisi-sisinya $10 \mathrm{~cm}, 8 \mathrm{~cm}$, dan $6 \mathrm{~cm}$ !"

Berikut lembar jawaban siswa :

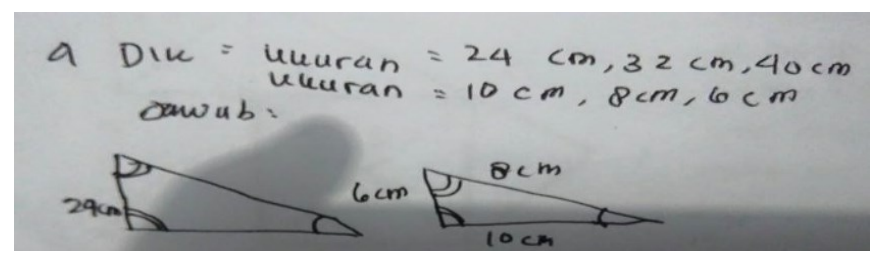

Gambar 4. Jawaban Tertulis Soal Nomor 4

\section{Analisis kesalahan}

Siswa yang mengerjakan soal tersebut belum memahami mengenai pertanyaannya, dan siswa tersebut tidak menuliskan hasil akhirnya, karena yang ditanyakan apakah terdapat kesebangunan dari kedua segitiga tersebut, siswa hanya meembuat segitiga nya saja dan pengerjakan belum tuntas. 


\section{Wawancara}

P : "Nenden kenapa jawabannya tidak diberi kesimpulan? "

$\mathrm{S}$ : " Tidak bu, Nenden bingung karena belum tahu arti kongruen bu."

P : "Begitu ya, jadi Nenden hanya menggambar ya? "

S : "Iya bu."

Berdasarkan wawancara tersebut, subjek belum memahami mengenai materi tersebut dan belum mengerti unsur - unsur dari soal yang diberikan.

Untuk soal no 5 itu dilihat dari indikator yang kelima dari kemampuan penalaran matematik yaitu mengajukan lawan contoh.

Berikut lembar jawaban siswa :

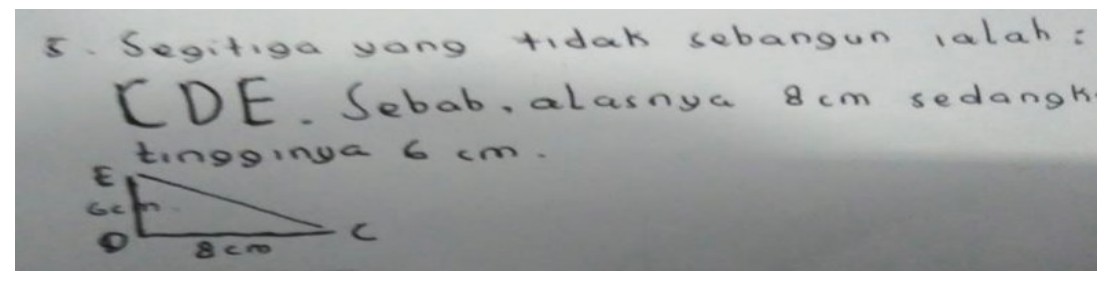

Gambar 5. Jawaban Tertulis Soal Nomor 5

\section{Analisis kesalahan}

Siswa yang mengerjakan soal tersebut belum memahami mengenai konsep, karena dalam soal sudah dijelaskan bahwa segitiga CDE itu merupakan segitiga yang sebangun dengan segitiga CJB dan CED, sedangkan yang ditanyakan adalah mencari segitiga yang tidak sebangun, maka jawaban siswa ini tidak sesuai.

\section{Wawancara}

P : “ Zahra kenapa memilih segitiga yang sudah diketahui pada soal?"

S : "Zahra bingung bu soalnya banyak segitiganya."

P : “ begitu ya, Zahra paham segitiga yang tidak sebangun itu seperti apa?"

$\mathrm{S}$ : " iya tahu bu, tapi saat lihat soal jadi bingung lagi bu."

Berdasarkan wawancara diatas, subjek belum bisa dalam menentukan perbedaan dari segitiganya, sehingga subjek kesulitan dalam menjawabnya.

Untuk soal no 6 itu dilihat dari indikator yang keenam dari kemampuan penalaran matematik yaitu memperkirakan jawaban dan proses solusi, berikut soalnya :

"Sebuah taman berbentuk persegi panjang, dan akan dibangun taman didalamnya berbentuk segitiga sama kaki dengan panjang sisi yang sama $15 \mathrm{~m}$, panjang sisi lainnya $12 \mathrm{~m}$, dan tinggi $7 \mathrm{~m}$. Jika taman tersebut akan ditanami rumput dengan biaya Rp. 60.000/ $\mathrm{m}^{2}$. Apakah dengan uang Rp. 1.000.000 ,- cukup untuk membangun taman tersebut? ”

Berikut lembar jawaban siswa :

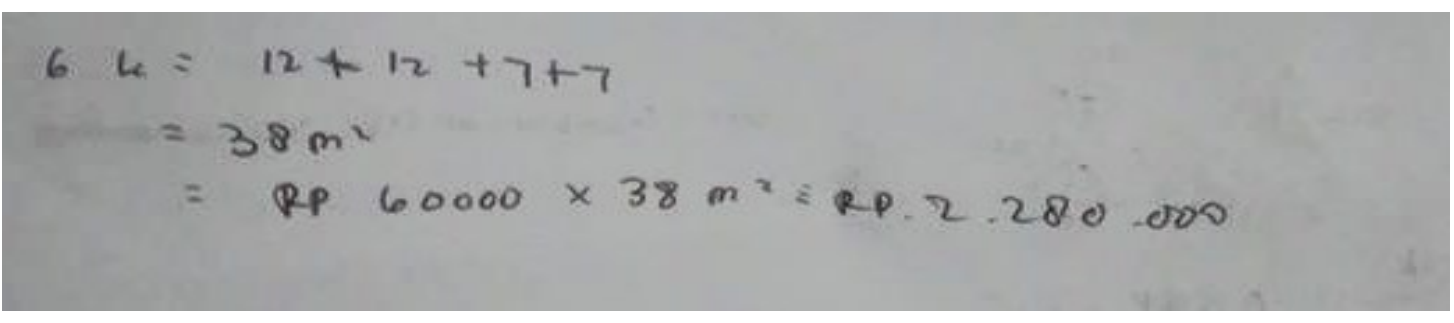

Gambar 6. Jawaban Tertulis Soal Nomor 6 


\section{Analisis kesalahan}

Siswa yang mengerjakan soal tersebut hasilnya kurang tepat, atau salah mengenai cara pengerjaannya, karena siswa tersebut langsung menghitung luas persegi panjangnya saja tanpa diperhatikan bahwa luas segitiga lah yang seharusnya dicari yang kemudian nanti diketahui biaya yang diperlukan untuk membangun taman tersebut sesuai soal yang diberikan.

\section{Wawancara}

P : " Hadiyan sudahkah mengerti tentang soalnya?"

S : "Iya sedikit bu, soalnya Hadiyan bingung harus nyari luas yang segitiga atau persegi panjangnya."

P : “ kenapa Hadiyan memilih mencari luas yang persegi panjang?'

S : "Hadiyan hanya tahu nya yang itu bu."

Berdasarkan wawancara diatas, subjek masih kesulitan teradap konsep, subjek hanya menjawab yang diketahuinya saja, sehingga jawaban tidak sesuai.

Untuk soal no 7 itu dilihat dari indikator yang keenam dari kemampuan penalaran matematik yaitu Menggunakan Pola Hubungan untuk menganalisis,membuat analogi, generalisasi, dan menyusun serta menguji konjektur, berikut soalnya :

"Berikut ini adalah gambar daerah kolam renang yang berbentuk persegi panjang dengan ukuran $30 \mathrm{~m}$ X $15 \mathrm{~m}$. Kolam untuk berenang berbentuk belah ketupat, jika titik - titik sudut belah ketupat berada ditengah-tengah sisi terluar daerah tersebut. Berapakah luas daerah diluar kolam yang digunakan?". Berikut lembar jawaban siswa :

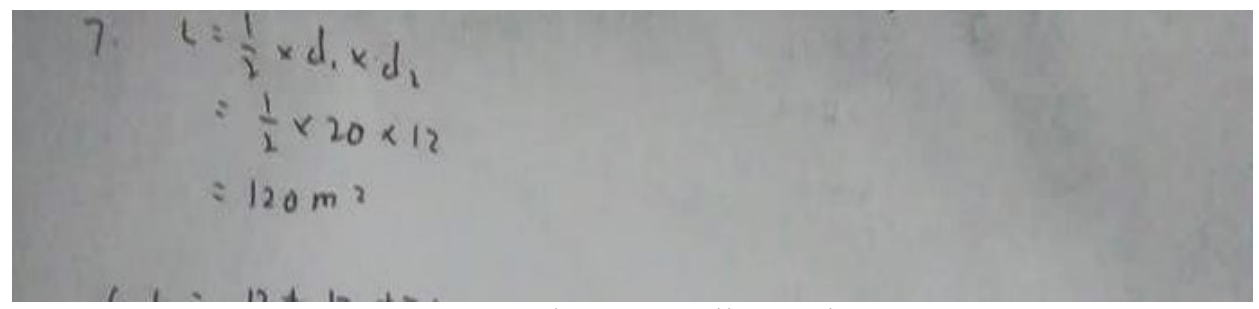

Gambar 7. Jawaban Tertulis Soal Nomor 7

\section{Analisis kesalahan}

Siswa yang mengerjakan soal tersebut tidak mengerti dengan apa yang ditanyakan dari unsur - unsur soal tersebut, sehingga jawaban siswa tersebut tidak lengkap hanya sebagian saja, dan tidak terdapat kesimpulan terhadap hasil akhirnya, karena seharusnya kedua luasnya dicari, dan hasil akhirnya dikurangi dari kedua luas tersebut sehingga masuk kedalam sebuah kesimpulan.

\section{Wawancara}

P : "Kenapa hanya menjawab luas dari belah ketupatnya saja?"

$\mathrm{S}$ : " Karena belum mengerti bu dengan soalnya dan materinya."

P : "Belajar lagi ya nanti untuk materi ini."

S : "Iya bu."

Berdasarkan wawancara diatas, subjek mengalami kesulitan dalam memahami konsep.

\section{KESIMPULAN}

Berdasarkan hasil penelitian dan pembahasan yang telah diuraikan, maka dapat diambil kesimpulan yaitu kemampuan penalaran siswa SMP pada materi segitiga dan segiempat 
termasuk dalam kategori cukup. Hal ini dapat dilihat dari total presentase yang diperoleh oleh siswa sebesar $45 \%$. Mengenai Faktor - faktor yang mempengaruhi tingkat penalaran matematika siswa diantaranya Siswa kurang teliti dalam memahami permasalahan yang diberikan, Siswa kurang paham terhadap penguasaan konsep materi segitiga dan segiempat, Siswa tidak mempunyai ide dalam memecahkan persoalan sehingga siswa hanya mampu sampai tahap memahami masalah.

\section{DAFTAR PUSTAKA}

Adegoke, B. A. (2013). Modeling the Relationship between Mathematical Reasoning Ability and Mathematics Attainment. Journal of Education and Practice, 4(17): 222.

Arikunto, S. (2009). Dasar-dasar Evaluasi Pendidikan. Bumi Aksara. Jakarta: Bumi Aksara.

Arikunto, S. (2011). Dasar-dasar Evaluasi Pendidikan. Rineka Cipta. Jakarta: Rineka Cipta.

Hermawan, A. S., \& Hidayat, W. (2018). Meningkatkan Kemampuan Penalaran Matematik Siswa SMP Melalui Pendekatan Penemuan Terbimbing. JPMI (Jurnal Pembelajaran Matematika Inovatif), 1(1), 7-20.

Hidayat, W. (2017). Adversity Quotient dan Penalaran Kreatif Matematis Siswa SMA dalam Pembelajaran Argument Driven Inquiry pada Materi Turunan Fungsi. KALAMATIKA Jurnal Pendidikan Matematika, 2(1), 15-28.

Hidayat, W., \& Prabawanto, S. (2018, January). Improving students' creative mathematical reasoning ability students through adversity quotient and argument driven inquiry learning. In Journal of Physics: Conference Series (Vol. 948, No. 1, p. 012005). IOP Publishing.

Hidayat, W., \& Sariningsih, R. (2018). Kemampuan Pemecahan Masalah Matematis dan Adversity Quotient Siswa SMP Melalui Pembelajaran Open Ended. JNPM (Jurnal Nasional Pendidikan Matematika), 2(1), 109-118.

Hutajulu, M. (2010). Peningkatan Kemampuan Pemahaman dan Penalaran Matematik Siswa Sekolah Menegah Atas Melalui Model Pembelajaran Inkuiri Terbimbing (Studi Eksperimen pada Siswa Kelas X SMA Negeri 15 Bandung). Tesis Pasca Sarjana Universitas Pendidikan Indonesia. Bandung: Pasca Sarjana Universitas Pendidikan Indonesia.

Isnaeni, S., Fajriyah, L., Risky, E. S., Purwasih, R., \& Hidayat, W. (2018). Analisis Kemampuan Penalaran Matematis dan Kemandirian Belajar Siswa SMP pada Materi Persamaan Garis Lurus. Journal of Medives, 2(1), 107-116.

Nawawi, H. (2005). Metode Penelitian Bidang Sosial. Gajah Mada University Press. Yogyakarta: Gajah Mada University Press.

Riyanto, B. (2011). Meningkatkan Kemampuan Penalaran dan Prestasi Matematika dengan Pendekatan Kontruktivisme pada Siswa Sekolah Menengah Atas. Jurnal Pendidikan Matematika 5 (2). 
Riyanto, B., \& Siroj, R. A. (2011). Meningkatkan Kemampuan Penalaran dan Prestasi Matematika dengan Pendekatan Konstruktivisme Pada Siswa Sekolah Menengah Atas. Jurnal Pendidikan Matematika, 5(2), 111-128.

Sholihat, N. A. N., Hidayat, W., \& Rohaeti, E. E. (2018). PENGHARGAAN DIRI DAN PENALARAN MATEMATIS SISWA MTS. JPMI (Jurnal Pembelajaran Matematika Inovatif), 1(3).

Slameto. (2010). Belajar \& Faktor-Faktor yang Mempengaruhi. Rineka Cipta. Jakarta: Rineka Cipta.

Sobur, A. (2003). Psikologi Umum. Pustaka Setia. Bandung: Pustaka Setia.

Widjaya, W. (2010). Design Realistic Mathematics Education Lesson. Makalah Seminar Nasional Pendidikan, Program Pascasarjana Universitas Sriwijaya.

Yusdiana, B. I., \& Hidayat, W. (2018). ANALISIS KEMAMPUAN PENALARAN MATEMATIS SISWA SMA PADA MATERI LIMIT FUNGSI.JPMI (Jurnal Pembelajaran Matematika Inovatif), 1(3). 
818 Astuti, \& Sariningsih, Analisis Kemampuan Penalaran Matematik Siswa SMP Pada ... 